\title{
The Social Attitude Empowerment of Biology Students: Implementation JiRQA Learning Strategy in Different Ethnics
}

\author{
Yakobus Bustami \\ Biology Education Study Program, STKIP Persada Khatulistiwa Sintang, Indonesia, \\ ybustami07@gmail.com
}

\author{
Aloysius Duran Corebima \\ Indonesia,durancorebima@gmail.com

\section{Endang Suarsini} \\ Dr., Biology Department, State University of Malang, Indonesia

\section{Ibrohim} \\ Dr., Biology Department, State University of Malang, Indonesia
}

Prof., corresponding author, Biology Department, State University of Malang,

The empowerment of social attitudes in higher education is indispensable. The aim of this research was to uncover the effect of the empowerment efforts on the social attitudes of multiethnic biology students through the implementation of JiRQA learning strategy. This research was a quasi experimental of $2 \times 3$ factorial design implemented on the multiethnic biology students of STKIP Persada Khatulistiwa Sintang. The total sample was 125 students consisting of ethnics of Dayak, Malay and Javanese. The samples were taken by using simple random sampling technique. The data of social attitudes were obtained from SSAQ. The data were analyzed by using analysis of covariance (ANCOVA) at the 5\% significance level $(p<0.05)$. The results of the analysis showed that the JiRQA learning strategy was more potential in empowering social attitudes of biology students. All the three ethnic groups did not have different social attitudes on each learning strategies due to the acculturation and assimilation.

Keywords: biology students, ethnics, JiRQA strategy, learning strategy, social attitudes

\section{INTRODUCTION}

Humans are social creatures (Frith \& Wolpert, 2004; Blake \& Shiffrar, 2007; Tomasello, 2014) that cannot live individually without the help from others. Humans will always have a relation with each other to fulfill all of their necessities of life

Citation: Bustami, Y., Corebima, A. D., Suarsini, E. \& Ibrohim (2017). The Social Attitude Empowerment of Biology Students: Implementation JiRQA Learning Strategy in Different Ethnics. International Journal of Instruction, 10(3), 15-30. https://doi.org/10.12973/iji.2017.1032a 
(Purwaaktari, 2015), which require humans to have collaboration skill (in collaboration) in order to survive the challenges of the global society today (Trilling \& Fadel, 2009; Rotherham \& Willingham, 2009; Greenstein, 2012). The collaboration skill will be able to make the individuals to interact with each other, so that the social attitudes as the objectives of education can be enhanced.

There have been many appeals to build up the social attitudes in the field of education. UNESCO (1996) expressed the ideas about the importance of social attitudes written at one of the education pillars, that was "learning to live together". Furthermore, the research by Ramalingam et al. (2014) also reveals that higher education has an important role in assessing affective (attitude), psychomotor and cognitive aspects. Among the three aspects, the attitude aspect, such as spirituality and sociability, becomes the primary point that should be possessed by every graduate.

Social attitudes are required in everyday life, and can be used as a provision to place ourselves, so that we can socialize and interact in families, communities, and schools or colleges. The good interaction will be able to create a harmonious and peaceful life. Social attitudes are also needed in the learning process. The students having good social attitudes will be able to establish a good cooperation to achieve the learning objectives. In addition, social attitudes have an effect on the students' learning results (Parke \& Clarke-Stewart, 2011). The effect of social attitudes on the learning results can be seen from the results of the experimental research conducted in STKIP Persada Khatulistiwa Sintang showing that the contribution of social attitudes on the learning results in the conventional class was $8.80 \%$ and in the experimental class was $2.00 \%$.

Based on this reality, the empowerment of social attitudes in higher education is indispensable. But in fact, many problems related to poor social attitudes can still be found, especially among the students of biology education in STKIP Persada Khatulistiwa Sintang. The results of the observation showed that there were students who did not have a responsibility (35.97\%), and did not respect friends of different ethnic, religions, race, cultures, and gender $(30.70 \%)$, and those did not want to cooperate with the other ethnic groups (34.21\%). If this situation was left unchecked, it could lead to social friction on the students of multiethnic background.

As a multiethnic country, Indonesia often experiences some social frictions between ethnic groups. Many examples of friction or social conflicts taken place are caused by the ethnic differences, such as in Aceh, Kalimantan, Poso, Maluku and North Molluccas (Darmadi, 2011). The social conflicts can be overcome as soon as possible through a multiethnic education integrated in the learning process (Bank, 2002; Clarry, 2004; and Rachmawati, 2014).

The importance of multicultural education has been revealed by several previous researches. Bahtiar (2015) revealed that multiethnic education always upheld the values of heterogeneity and plurality in an ethnically diverse society. Multiethnic education is regarded as a resistance to fanaticism that leads to violence prevention. Multiethnic education is able to accommodate the differences of ethnics in harmony, tolerance, and mutual respect, and it is expected to be a pillar of peace, prosperity and harmony in the 
society, so that it can enhance the students' character through the development of mutual respect among ethnic groups (Tilaar, 2009).

One of learning strategies to integrate the multiethnic education into the learning process is a cooperative learning strategy (Kadir et al., 2005; Darmadi, 2011; and Bahtiar, 2015), including the Jigsaw, Reading, Questioning, Answering (JiRQA) strategies. JiRQA learning strategy is the integration of the syntax between Jigsaw learning and Reading, Questioning, Answering (RQA) learning strategy, with seven stages as follows: (1) stating the topic of the learning, (2) forming original heterogeneous groups, (3) Reading, Questioning, Answering activities in the original groups, (4) forming expert groups, (5) discussion in expert groups (6) discussion and peer tutors in the original groups, (7) giving quizzes and giving group rewards as well as giving homework to read and summarize the related material to be studied.

The results of various researches have revealed that the implementation of cooperative learning strategies was capable of empowering the social attitudes of multiethnic students (Bleszynska, 2008; Boleng \& Corebima, 2014; Bahtiar, 2015). The research of Bleszynska (2008) revealed that the implementation of cooperative learning strategies reduced the individualism, xenophobia and ethnocentric character of multiethnic students and prevented social conflicts as well as formed harmony in a pluralistic society. Cooperative learning strategies have proven to have a positive effect on social competence (Cohen \& Lotan, 1995; Ginsburg-Block et al., 2006; Roseth el.al., 2008) and when implemented to different ethnic groups, it could enhance the relations among ethnics at school (McKown, 2005). The established relationship makes an inter-ethnic assimilation, so that it creates the character values such as harmonious and peaceful which eventually strengthen the social attitudes of multiethnic students.

\section{Framework and Hypothesis}

Based on the framework for implementation of JiRQA learning strategy to empower social attitudes of multiethnic students is cooperative learning, with six dimensions as follows: (1) mutual dialogue and arguments, (2) creating social interactions, (3) developing a common purpose, (4) group and individual learning, (5) interdependence, (6) collaboration learning (Slavin, 2010). We use this framework in our research to develop hypothesis. Hypothesis in this research is JiRQA learning strategy can empower social attitudes of multiethnic students.

\section{Aims of the Research}

The aim of this research was to uncover the empowerment efforts on the social attitudes of biology multiethnic students through the implementation of JiRQA learning strategy. This research is expected to be a reference to apply the JiRQA learning strategies to the multiethnic students in empowering their social attitudes. 


\section{METHOD}

\section{Research Design}

This was a quasi-experimental research using Nonequivalent Control Group Design consisting of two factors $(2 \times 3)$. The first factor was the kind learning strategy (consisting of two learning: JiRQA learning and conventional learning). The second factor was multiethnic students consisting of three ethnics namely Dayak, Malay and Javanese. The kind learning and ethnicity were the independent variables while the social attitudes were the dependent variables. The design of this research can be seen in Table 1.

Table 1

Research design

\begin{tabular}{lll}
\hline Pretest & Treatment & Posttest \\
\hline O1 & S1E1 & O2 \\
\hline O3 & S1E2 & O4 \\
\hline O5 & S1E3 & O6 \\
\hline O7 & S2E1 & O8 \\
\hline O9 & S2E2 & O10 \\
\hline O11 & S2E3 & O12 \\
\hline
\end{tabular}

(A modification from Fraenkel \& Wallen, 1993)

Note:

$\mathrm{S} 1=\mathrm{JiRQA}$ learning

$\mathrm{S} 2=$ conventional learning

O1, O3, O5, O7, O9, O11 = Pretest Score

$\mathrm{E} 1=$ Dayak ethnic

$\mathrm{E} 2=$ Malay ethnic

$\mathrm{O} 2, \mathrm{O} 4, \mathrm{O} 6, \mathrm{O} 8, \mathrm{O} 10, \mathrm{O} 12$ = Posttest Score

E3 = Javanese ethnic

\section{Population and Sample of the Research}

This research was conducted at STKIP Persada Khatulistiwa Sintang, Indonesia. The population of this research was all the students of biology education program with the total of 586 students. The sample of this research was the students who programmed zoology course on the even semester of the 2015/2016 academic year with the total sample of 125 students. The sample consisted of three ethnics, namely Dayak (49 students), Malay (37 students), and Javanese (39 students). The sample of the experiment class was taken by using simple random sampling technique based on the equality level of their academic ability. The results of the placement test indicated that all the samples had equal academic ability.

\section{Research Instrument}

The instrument used to measure the students' social attitudes was a questionnaire sheet called as Student Social Attitudes Questionnaire (SSAQ). SSAQ was developed based on the Likert scale questionnaire with the statement of Strongly Agree (SA), Agree (A), Disagree (D), and Strongly Disagree (SD). The total statement of SSAQ was 30 items. SSAQ was the modified version of Maasawet (2009) with some indicators of social attitudes, namely honesty, discipline, attitude, responsibility, tolerance, cooperation, 
confidence, and democratic plurality attitude. SSAQ had been validated by a team of experts (content and construct validation) and had been tried out (empirical validation). Content and construct validity has been obtained through validation conducted by a team of experts, while the empirical validity has been obtained by the try-out of the instrument. The results of the empirical validation showed that all the items were valid and reliable (product moment value ranged from 0.309 to 0.676 and Cronbach alpha values ranged from 0.872 to 0.881 ).

\section{Data Collection and Analysis}

The data of the social attitudes collected by using SSAQ questionnaire given to all the research sample, was obtained before and after the treatment. The answers of the students' statements were scored based on the Likert scale score of 1-4 and then it was converted to another score ranging $0-100$, based on 30 items; student score of 0 has been, scored as 0 , and student score of 120 has been, scored as 100.The data obtained were then summarized and analyzed.

The prerequisite test for each learning strategy was conducted related to normality and homogeneity. The results of the prerequisite tests, both the pretest and posttest for each learning strategy showed a normal and homogeneous distribution (value: $p>0.05$ ); the normality value of pretest and posttest was 0.633 and 0.361 respectively as well as, the homogeneity value of pretest and posttest was 0.630 and 0.747 respectively. The data analysis was performed using analysis of covariance (ANCOVA) at the significance level of 5\% (value: $\mathrm{p}<0.05$ ), and then continued with the Least Significant Difference (LSD) test, if the results of the ANCOVA were significantly different. All the data analysis used SPSS version 16.

\section{FINDINGS}

The results of the descriptive analysis [Table 2] show that all ethnics in the conventional learning had a lower increase than that of all the ethnics in the JiRQA learning strategy. The increase in JiRQA produced the social attitudes in very good category. It was different from the conventional learning that achieved good category.

Table 2

Summary of Mean Score of social Attitudes of the multiethnic Students

\begin{tabular}{lccccccc}
\hline $\begin{array}{l}\text { Learning/Learning } \\
\text { strategy }\end{array}$ & $\begin{array}{c}\text { Ethnic } \\
\text { groups }\end{array}$ & $N$ & $\begin{array}{c}\text { Pretest } \\
\text { mean }\end{array}$ & Category & $\begin{array}{c}\text { Posttest } \\
\text { mean }\end{array}$ & Category & $\begin{array}{c}\text { Increase } \\
(\%)\end{array}$ \\
\hline JiRQA & Dayak & 26 & 77.92 & Good & 84.10 & Very good & 7.94 \\
\hline & Malay & 18 & 74.49 & Good & 83.66 & Very good & 12.30 \\
\hline Java & 20 & 74.58 & Good & 84.63 & Very good & 11.89 \\
\hline Total & 64 & 75.91 & Good & 84.14 & Very good & 10.84 \\
\hline & Dayak & 23 & 76.23 & Good & 77.14 & Good & 1.19 \\
\hline Malay & 19 & 77.28 & Good & 77.94 & Good & 0.85 \\
\hline Java & 19 & 75.83 & Good & 79.21 & Good & 4.45 \\
\hline & Total & 61 & 76.43 & Good & 78.03 & Good & 2.09 \\
\hline
\end{tabular}

Note $\mathrm{N}=$ Number of students 
The summary of the results of ANCOVA related to the effect of learning strategy, ethnics, and the interaction between learning strategy and ethnics on the social attitude of biology students can be seen in Table 3 .

Table 3

Summary of the Results of ANCOVA on the social Attitudes of multiethnic Students

\begin{tabular}{llllll}
\hline Source & Type III Sum of Squares & $d f$ & Mean Square & $F$ & Sig. \\
\hline Corrected Model & 1404.815 & 6 & 234.136 & 8.817 & .000 \\
\hline Intercept & 4064.346 & 1 & 4064.346 & 153.055 & .000 \\
\hline X Social & 172.177 & 1 & 172.177 & 6.484 & .012 \\
\hline Strategy & 1181.145 & 1 & 1181.145 & 44.479 & .000 \\
\hline Ethnics & 59.250 & 2 & 29.625 & 1.116 & .331 \\
\hline Strategy * Ethnics & 6.272 & 2 & 3.136 & .118 & .889 \\
\hline Error & 3133.473 & 118 & 26.555 & & \\
\hline Total & 819326.000 & 125 & & & \\
\hline Corrected Total & 1404.815 & 6 & 234.136 & 8.817 & .000 \\
\hline
\end{tabular}

The results of ANCOVA [Table 3] show that learning strategy had an effect on social attitudes $(\mathrm{p}=0.000<0.05)$, while ethnics and the interaction between learning strategy and ethnics did not have an effect on social attitudes of biology students $(p=0.889>$ 0.05 ). The results of ANCOVA related to the learning strategy potency show that JiRQA was $8.00 \%$ higher and significantly different from the conventional learning. These results indicate that the JiRQA learning strategy is more capable to increase the social attitudes of biology students than the conventional learning.

Related to the interaction between learning strategy and ethnics, although it was proved having no effect, it could be continued with LSD test to determine the differences of the mean score of the combination group. The results of post hoc test related to the effect of the interaction between learning strategy and ethnics on the social attitudes of biology students can be seen in Table 4.

Table 4

Summary of the LSD Notation related to the Mean Score of the corrected social Attitudes

Learning/Learning strategy Ethnic groups Xsocial Ysocial Difference Cor value LSD Notation

\begin{tabular}{llllllll}
\hline Conventional & Dayak & 76.23 & 77.14 & 0.91 & 76.71 & a & \\
\hline & Malay & 77.28 & 77.94 & 0.66 & 77.23 & a & \\
\hline & Java & 75.83 & 79.21 & 3.38 & 78.86 & a & b \\
\hline JiRQA & Total & 76.43 & 78.03 & 1.60 & 77.60 & a & b \\
\hline & Dayak & 77.92 & 84.10 & 6.18 & 83.42 & & b \\
\hline & Malay & 74.49 & 83.66 & 9.17 & 83.52 & & b \\
\hline & Java & 74.58 & 84.63 & 10.05 & 84.49 & & 83.81 \\
\end{tabular}

The results of the post hoc analysis of LSD test in Table 4 show that the social attitudes of biology students among ethnics are not significantly different in the two learning 
groups respectively. The results of LSD test related to the combination group of learning and ethnic group are in line with the results of the post hoc test related to the strategy.

The computation result of effect size related to ANCOVA tests is presented in Table 5. It indicates that the effect size of the learning strategy to social attitude classified as high, while the effect size of ethnics as well as the effect size of their interaction classified as low (the interpretation of the effect size was based on Cohen, 1988).

Table 5

Computation result of effect size for ANCOVA test

\begin{tabular}{lll}
\hline Source & Partial Eta Squared & Effect Size \\
\hline Learning strategy & 0.270 & High \\
\hline Ethnics & 0.019 & Low \\
\hline Interaction strategy-ethnics & 0.002 & Low \\
\hline
\end{tabular}

\section{DISCUSSION}

The results of the descriptive analysis show that the increase in the social attitudes mean score of biology students in all ethnics in the JiRQA learning strategy is bigger than that of the conventional learning. The increase in the JiRQA learning strategy produces the social attitudes achieving a very good category. It is different from that of the conventional learning achieving a good category. The results of this research are consistent with the results of the research by Lewis \& Tran (2012) and Witariani (2014) showing that the implementation of cooperative learning strategies in the experimental class experienced an increase in the mean score of the social attitude category better than that in the conventional classroom.

The results of the ANCOVA related to the effect of learning strategy on the student social attitudes show that the learning strategy has a significant effect. JiRQA learning strategy has an average value of the corrected social attitudes $8.00 \%$ higher and significantly different from the conventional learning. The findings of this research were in line with the results of the research conducted by Maasawet (2009) as well as by Bahtiar (2013) and Boleng \& Corebima (2014) by implementing cooperative learning strategies namely Snowballing and Number Head Together (NHT), Think-Pair-Share (TPS) and Reading Questioning Answering (RQA), Cooperative Script and Think-PairShare (TPS) respectively.

The higher increase of the social attitudes of biology students experiencing the JiRQA learning strategy is caused by the fact that this strategy has more advantages when compared to the conventional learning. The superiority of the JiRQA learning strategy cannot be separated from the syntax or stages on each learning activity combined. The discussion activities in the original group and expert group will be able to encourage biology students to have a mutual dialogue and arguments without distinction of ethnicity. The activity is able to foster the plurality and democratic attitudes of the learning process. According to Ravitch (2010), the essence of the practice of democracy is to learn making an argument peacefully in different groups and to cooperate in groups with all the existing differences. 
On the other hand, the cooperation activities in JiRQA learning will be able to create social interactions among biology students. The interaction will be able to develop an attitude of mutual tolerance, mutual care and mutual support among students. The statement is in line with the research conducted by Laal \& Ghodsi (2011) and Lewis \& Tran (2012) stating that the cooperation in the cooperative learning strategies fosters the students' attitude to be more caring and more supportive in the relationship of friendship, and enables the learners to develop their social skills (Kocak, 2008). Furthermore, the research of Ayon (2013) also revealed that the cooperation in the cooperative learning could develop the students' tolerance attitude. The tolerance attitude can foster the mutual respect among the biology students in the learning process.

JiRQA learning strategy also provides the opportunity for all biology students to read, make a resume, ask questions, and answer and submit their assignments on time, and it encouraged the biology students to be discipline and honest with his work. The results of the work are of their own thinking in their groups and not the results of cheating from the other friends, so that each student is responsible for the task given to him/her. The research of Dooly (2008) also revealed that cooperative learning could improve their responsibility, both the responsibility toward themselves and the responsibility toward others.

The increase of the social attitudes of biology students at JiRQA strategy cannot be separated from the peer tutor activities in groups. Peer tutoring activities on JiRQA learning strategy will "force" every student to share or present their parts of the learning materials to their friends. The courage to present the learning materials can foster their confidence which will ultimately enhance their cognitive abilities (Juweto, 2015; and AlSalkhi, 2015). Peer tutoring activities can also encourage the students to be responsible of their parts of the learning materials and to learn together in order to achieve their common goal (Slavin, 2010). The responsibility of each individual can strengthen all aspects of capabilities including the social attitudes of biology students.

A different thing occurs in the conventional learning. The conventional learning process do not really encourage the biology students to develop the attitude of cooperation, honesty, discipline, responsibility, tolerance and inter-ethnic democratic attitude in the learning process. The research by Boleng et al. (2013) revealed that the decline of the students' social attitudes in conventional classes was related to the fact that the learning activities were dominated by the teacher, and the students did not really have the opportunity to interact with each other, so that it gave a less positive impression about the meaning of socialization and cooperation to help each other in the classroom.

The results of ANCOVA related to the effect of ethnics on social attitudes showed that ethnics did not have a significant effect on the social attitudes of biology students. The results of this research were not in line with the results of the previous researches conducted by Maasawet (2009) on students in relation with ethnics of Javanese, Bugis, Banjar and Kutai, and the research by Boleng \& Corebima, (2014) on students in relation with ethnics of Javanese, Banjar, Bugis, and Kutai, stating that ethnics had a significant effect on the students' social attitudes. The difference between the results of this research and that of the previous researches was caused by the fact that the student 
characteristics in relation with ethnics of Dayak, Malay and Javanese in this research had undergone the process of acculturation. The process of acculturation have occurred because the Javanese and Malay students, as the immigrant ethnics, have been living together with the local ethnics (Dayak) in West Kalimantan long time ago, causing immigrant ethnics underwent a process of adjustment and social culture shift. Thus, it eventually led to a reduction in the difference of socio culture on each ethnics.

The research by Berry (2005) and Celenk \& Van de Vijver (2011) revealed that acculturation was the process of cultural, psychological, and social changes in which people coming from different backgrounds and living continuously in quite a long time with the culture of others' leads to the creation of the same socio culture for every individual. The process of acculturation that occurred would be able to reduce the differences in social attitudes of the biology students in all the three ethnic groups. The results of this research were not in line with the research by Haerullah (2012) which revealed that the reduction of ethnic differences through the process of acculturation process did not have any effect on the differences in the social attitudes of multiethnic students.

On the other hand, the characteristics of the ethnics of Dayak, Malay and Javanese can build the social interaction among ethnics in a group. The research by Duda (2015) revealed that the character of Dayak ethnics was always able to mingle with the other ethnic groups because of marriage or the other causes. Moreover, Dayak ethnics as a local ethnic appreciates and cares very much for the other non-Dayak people. The same thing also occurs at Malay ethnics. Malay ethnics, as the second largest ethnic group in West Kalimantan, has a character with good hospitality toward each other and toward their environment, so that the Malay ethnics find it easy to interact with the other ethnics. Related to the Javanese ethnics, the research of Maasawet (2009) revealed that the Javanese has the principles of respect, which is manifested in the forms of shyness, easily accept any situation, tolerance and easily adapt to the surrounding environment. Characteristics possessed by all the three ethnic groups can also reduce the differences in social attitudes among the biology students.

The results of ANCOVA related to the effect of the interaction between learning strategy and ethnics on the social attitudes show that the interaction does not have a significant effect on the social attitudes of biology students. The result of this research related to the interaction effect is not in line with the research results of Maasawet (2009) implementing cooperative learning's of Snowballing and Number Head Together (NHT), as well as the research results of Boleng \& Corebima (2014) implementing Cooperative Script and Think-Pair-Share (TPS). The difference is associated with the different characteristics of the strategies and ethnics used in the previous researches.

Although it did not show a significant effect, to reveal more information about this research, the post hoc test is performed in order to know the differences of the social attitudes in each combination group between learning strategy and ethnics. The results of LSD test showed that the social attitude in both groups of the combination between strategies and ethnics was not significantly different. This phenomena is caused by the 
process of acculturation and the character values of each ethnics, so that there was not any difference in the social attitudes of each ethnics.

The process of assimilation occurring in the STKIP Persada Khatulistiwa Sintang also influence the social attitudes of the biology students. STKIP Persada Khatulistiwa Sintang as a higher education institution in West Borneo located in the multiethnic region has instilled social attitudes, such as honesty, discipline, responsibility, tolerance, cooperation, confidence and democratic plurality attitude through the activities of student activity units. Some activities of student activity units such as activities related to sports, religion, nature lovers, and the scouts are able to bring the process of assimilation in each ethnics, so that it create a similar social attitude in each multiethnic student. According to Liliweri (2009) when ethnic groups hold assimilation activity, they will identify themselves as a new group. The assimilation process is characterized by the development of the same attitudes, which, although sometimes emotional, aims to achieve unity, or at least to achieve integration in the organization and action.

The undifferent social attitudes in some combination of learning strategy and ethnic group were also possibly caused by the facts that some lecturers had instilled the social attitude through the learning process, especially cooperative learning. The results of the preliminary observation described that some lecturers implemented cooperative learning process, including Student Teams Achievement Division (STAD), Number Head Together (NHT), Jigsaw, and Make a Match. The implementation of cooperative learning strategy would provide equal opportunities for the students coming from different ethnic backgrounds to work in teams and to participate fully in the classroom, so that it strengthened the social attitudes among ethnics (Arends, 2008). The implementation of cooperative strategies are also able to form a heterogeneous group of the biology students in terms of ethnicity, gender and religion. The heterogeneity in the cooperative learning would also provide an equal opportunity for each ethnic group to develop the social attitudes of each ethnicity.

The findings of this research indicate that the JiRQA cooperative learning strategy has more potential in empowering the social attitudes of biology students in all the three ethnic groups. The findings of this research are in line with the researches conducted by Maasawet (2009), Haerullah (2012), and Boleng \& Corebima (2014), stating that the cooperative learning strategy has the potential to empower social attitudes of multiethnic learners. Some characteristics of JiRQA, when integrated with ethnicity, will be potential in empowering the social attitudes of multiethnic students.

JiRQA learning strategy is an interactive learning strategy centered on the students. The interactive learning process in the JiRQA learning strategy occurs through group discussions, reading, summarizing, asking questions, and answering their own questions in the group, as well as peer tutoring activity in the group activity. The activities in the JiRQA learning strategy can encourage the multiethnic students to be honest, discipline, responsible, caring, cooperative, and tolerant, without differentiating ethnicities, so that it will create the democratic process in learning. In addition, the activities in the JiRQA learning strategies are also able to establish harmonious inter-ethnic interaction in the 
learning process. The interaction that occurred in the JiRQA learning strategy would strengthen the social attitudes of the multiethnic students.

\section{CONCLUSION}

Based on the results of the data analysis and discussion, it can be concluded that: (1) learning strategies had an effect of the social attitudes of biology students. The increase of the social attitudes in JiRQA learning strategy is $8.00 \%$ higher than that on the conventional learning, (2) ethnic does not have any effect on the social attitudes of biology students, (3) the interaction between learning strategy and ethnics does not have any effect of the social attitude of biology students. In both learning, it is proven that the social attitudes of biology students at all ethnics are equal, caused by the acculturation and assimilation.

JiRQA learning strategy can be recommended to be implemented in the learning process as an effort to empower the social attitudes of multiethnic students. Universities need to implement cooperative learning strategies, especially the JiRQA strategy in improving the social attitudes of biology students. Furthermore, the researchers and lecturers need to conduct similar researches on different learning materials and different levels of education, and to use JiRQA learning strategy to measure the effect of this learning strategy on the other dependent variables, such as retention.

\section{REFERENCES}

Al-Salkhi, M. J. (2015). The effectiveness of jigsaw strategy on the achievement and learning motivation of the 7th primary grade students in the islamic education. International Journal of Humanities and Social Science, 5(4), 111-118.

Arends, R. I. (2008). Learning to Teach. Seventh Edition. New York: McGraw- Hill Company.

Ayon, N. S. (2013). Collaborative learning in english for specific purposes courses: Effectiveness and students'attitudes towards it. American Academic \& Schoolarly Research Journal, 5(3), 62-75.

Bahtiar. (2013). Potensi pembelajaran yang memadukan strategi Think Pairs Share (TPS) dan Reading Questioning Answering (RQA) untuk meningkatkan sikap sosial dan penguasaan konsep biologi siswa SMA multietnis di Ternate [The potential of learning strategy integrating Think Pairs Share (TPS) and Reading Questioning Answering $(R Q A)$ to improve the social attitude and biological concept mastery of multiethnic senior high school students in Ternate]. Proceeding Seminar Nasional X Biologi UNS Surakarta, 10(2), 48-54.

Bahtiar. (2015). Pembelajaran kooperatif untuk meningkatkan sikap sosial dan pemahaman konsep siswa sekolah multietnis [Cooperative learning to improve social attitudes and concept gaining of multiethnic school students]. Jurnal Edukasi Matematika dan Sains, 3 (1), 1-13. 
Banks, J. A. (2002). An Introduction to Multicultural Education. Boston: Allyn \& Bacon.

Berry, J. W. (2005). Acculturation: Living successfully in two cultures. International Journal of Intercultural Relations 29, 697-712.

Blake, R., \& Shiffrar, M. (2007). Perception of human motion. The Annual Review of Psychology, 58, 47-73.

Bleszynska, K. (2008). Cooperative learning and processes of individuation. Conference Venue: Via S.Ottavio 20, January 19-22. Turin, ITALY: The IAIE Regularly Organizes International Educational.

Boleng, D. T., Corebima, A. D., Susilo, H., \& Ibrohim. (2013). Pengaruh strategi pembelajaran cooperative script dan think-pair-share terhadap sikap sosial siswa SMA Samarinda multietnis [The effect of cooperative script and think-pair-share learning strategies on the social attitudes of multiethnic senior high school students in Samarinda]. Proceeding Seminar Nasional X Biologi UNS Surakarta, 10(2), 55-63.

Boleng D. T. \& Corebima, A. D. (2014). Cooperative learning models having better potency to improve social attitude of multiethnic senior high school students at Samarinda, Indonesia. Journal of Educational Research and Reviews, 2(3), 36-44.

Celenk, O., \& Van de Vijver, F. (2011). Assessment of acculturation: Issues and overview of measures. Online Readings in Psychology and Culture, 8(1), 1-22.

Clarry, S. (2004). Multicultural education in Kalimantan Barat; An overview. Jurnal Multicultural Education in Indonesia and South East Asia 1, 85.

Cohen, E. G. \& Lotan, R. A. (1995). Producing equal status interaction in the heterogeneous classroom. American Educational Research Journal 32, 99-120.

Darmadi. (2011). Membentuk Peradaban Bangsa Melalui Pendidikan Multietnik [Developing the nation civilization through multiethnic education]. Bandung: Alfabet.

Dooly, M. (Ed). (2008). Constructing Knowledge Together: A Guidebook to Moderating Intercultural Collaboration Online. Bern: Peter Lang.

Duda, H. J. (2015). Pengaruh model pembelajaran berbasis masalah melalui praktikum yang ditunjang asesmen autentik dan etnis terhadap kemampuan berpikir kritis, keterampilan proses sains, dan sikap ilmiah mahasiswa STKIP Persada Khatulistiwa Sintang pada matakuliah fisiologi [The effect of problem based learning model through practice supported by authentic assessment and ethnic on critical thinking skills, science process skills, and science attitudes of STKIP Persada Khatulistiwa Sintang students on physiology course]. Unpublished doctoral dissertation. Malang: State University of Malang.

Fraenkel, J. R. \& Wallen, N. E. (1993). How to Design And Evaluate Research In Education, $2^{\text {nd }}$ ed. New York: Mc Graw Hill. 
Frith, C. D. \& Wolpert, D. M. (2004). The Neuroscience of Sosial Interaction: Decoding, Imitating, And Influencing The Actions of Others. United States of America: Oxford University Press.

Greensteins L. (2012). Assessing $21^{\text {st }}$ Century skills. United States of America: Corwin.

Ginsburg-Block, M. D.; Rohrbeck, C. A. \& Fantuzzo, J. W. (2006). A meta-analytic review of sosial, self-concept, and behavioral outcomes of peer-assisted learning. Journal of Educational Psychology, 98(4), 732-749.

Haerullah. (2012). Pengembangan perangkat pembelajaran IPA Berpola Pemberdayaan Berpikir Melalui Pertanyaan (PBMP) dan Think Pair Share (TPS) serta pengaruh penerapannya terhadap metakognisi, berpikir kritis, dan sikap sosial siswa SD multietnis di kota Ternate [Developing science learning materials using Thinking Empowerment by Questioning (TEQ) learning and Think Pair Share (TPS) learning and the effect of its' implementation on metacognition, critical thinking, and social attitudes of multiethnic elementary students in Ternate]. Unpublished doctoral dissertation. Malang: State University of Malang.

Juweto, G. A. (2015). Effects of Jigsaw co-operative teaching/learning strategy and school location on students achievement and attitude towards biology in secondary school in Delta State. International Journal of Education and Research, 3(8), 31-40.

Kadir, S. A., Wong, S. L., Luan, W. S., Pihie, Z. A. L., Noran, F. Y., Yacob, N. F., Tarmizi, R. A. \& Elian, H. (2005). The effect of cooperative learning strategy on peer attachment. Pakistan Journal of Physiological Research, 20(4), 121-131.

Kocak, R. (2008). The effect of cooperative learning on psychological and sosial traits among undergraduate students. Sosial Behavior and Personality, 36(6), 771-782.

Laal, M. \& Ghodsi, S. M. (2011). Benefits of collaborative learning. Procedia-Social and Behavioral Sciences, 31, 486-490.

Lewis, R. \& Tran, V. D. (2012). The effects of jigsaw learning on students' attitudes in a Vietnamese higher education classroom. International Journal of Higher Education, 1(2), 9-20.

Liliweri, A. (2009). Makna Budaya Dalam Komunikasi Antar Budaya [Meaning of culture in intercultural communication]. Yogyakarta: PT LKiS Printing Cemerlang.

Maasawet, E. T. (2009). Pengaruh strategi pembelajaran kooperatif Snowballing dan Number Head Together (NHT) pada sekolah multietnis terhadap kemampuan berpikir kritis, hasil belajar kognitif sains biologi dan sikap sosial siswa SMP Samarinda [The effect of cooperative learning strategies Snowballing and Number Head Together (NHT) in multiethnic schools on the critical thinking skills, cognitive learning outcomes of biology and social attitudes of junior high school students Samarinda]. Unpublished doctoral dissertation. Malang: State University of Malang. 
McKown, C. (2005). Applying ecological theory to advance the science and practice of school based prejudice reduction interventions. Educational Psychologist, 40(3), 177189.

Parke. \& Clarke-Stewart. (2011). Social Development. New York: Wiley.

Purwaaktari, E. (2015). Pengaruh model collaborative learning terhadap kemampuan pemecahan masalah matematika dan sikap sosial siswa kelas V SD Jarakan Sewon Bantul [The effect of collaborative learning model on the problem solving ability and social attitudes of mathematics student class $\mathrm{V}$ of elementary school, Jarakan Sewon, Bantul]. Jurnal Penelitian Ilmu Pendidikan, 8(1), 95-111.

Slavin. (2010). Cooperative Learning: Theory Rearchand Practice. London: Allyn \& Barcon.

Ravitch, D. (2010). The Life and Death of The Great American School System: How Testing and Choice are Undermining Education. New York: Basic Books.

Rachmawati, Y. (2014). The necessity of multicultural education in Indonesia. International Journal of Education and Research, 2(10), 317-328.

Ramalingam, K.; Ramalingam, M. \& Chinnavan, E. (2014). Assessment of learning domains to improve student's learning in higher education. Journal of Young Pharmacists, 6(1), 27-33.

Roseth, C. J., Johnson, D. W. \& Johnson, R. T. (2008). Promoting early adolescents' achievement and peer relationships: The effects of cooperative, competitive, and individualistic goal structures. Psychological Bulletin, 134(2), 223-246.

Rotherham, A. J. \& Willingham D. (2009). $21^{\text {st }}$ Century skills: The challenges ahead. Educational Leadership, 67(1), 16-21.

Tilaar, H. A. R. (2009). Multikulturalisme Tantangan-Tantangan Global Masa Depan Dalam Transformasi Pendidikan Nasional [Multiculturalism as global challenges of the future in the national education transformation]. Jakarta: Grasindo.

Tomasello, M. (2014). A Natural History of Human Thinking. Cambridge, MA: Harvard University Press.

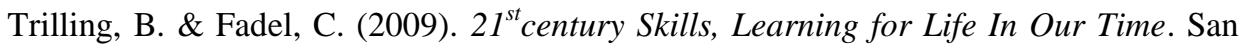
Francisco: Jossey-Bass.

UNESCO. (1996). Learning: The treasure within. Report to UNESCO of the International Commission on Education for the twenty-first century. Paris: UNESCO. 


\section{Turkish Abstract \\ Biyoloji Öğrencilerinin Sosyal Davranışlarının Güçlendirilmesi: Farklı Kültürlerdeki JiRQA Öğrenme Stratejileri}

Yüksek öğretimde sosyal davranıșların desteklenmesi zorunludur. Bu araștırmanın amacı, JiRQA öğrenme strateji uygulamalarıyla çok kültürlü biyoloji öğrencilerinin sosyal davranışlarının güçlendirilmesinin etkilerini ortaya çıkarmaktır. Örneklem Dayak, Malay ve Javanese kültürüne ait rasgele örnekleme tekniğiyle seçilmiş 125 öğrenciden oluşmaktadır. Sosyal davranış verileri SSAQ ile elde edilmiştir. Veriler, $\% 5$ anlamlılık düzeyinde $(\mathrm{P}<0.05)$ kovaryans analizi (ANCOVA) kullanılarak analiz edilmiştir. Analiz sonuçları JiRQA öğrenme stratejilerinin biyoloji öğrencilerinin sosyal davranışlarını güçlendirmede etkili olduğunu göstermektedir.

Anahtar Kelimeler: biyoloji öğrencileri, kültürler, JiRQA stratejileri, öğrenme stratejileri, sosyal davranışlar

\section{French Abstract \\ La Responsabilisation d'Attitude Sociale d'Étudiants de Biologie : Mise en œuvre JiRQA Apprentissage de Stratégie dans Membres d'une minorité ethnique Différents}

La responsabilisation d'attitudes sociales dans l'enseignement supérieur est indispensable. Le but de cette recherche était de découvrir l'effet des efforts de responsabilisation sur les attitudes sociales d'étudiants de biologie multiethniques par la mise en œuvre de JiRQA l'apprentissage de la stratégie. L'échantillon total était 125 étudiants consistant des membres d'une minorité ethnique de Dayak, le malais(le Malais) et le Javanais. Les échantillons été pris en utilisant technique d'échantillonnage aléatoire simple. Les données d'attitudes sociales ont été obtenues de SSAQ. Les données ont été analysées en utilisant l'analyse de covariance (ANCOVA) au niveau de signification de $5 \%$ (p 0.05). Les résultats de l'analyse ont montré que le JiRQA l'apprentissage de la stratégie était plus de potentiel dans les attitudes sociales autorisantes d'étudiants de biologie.

Mots Clés: étudiants de biologie, membres d'une minorité ethnique, JiRQA stratégie, apprenant stratégie, attitudes sociales

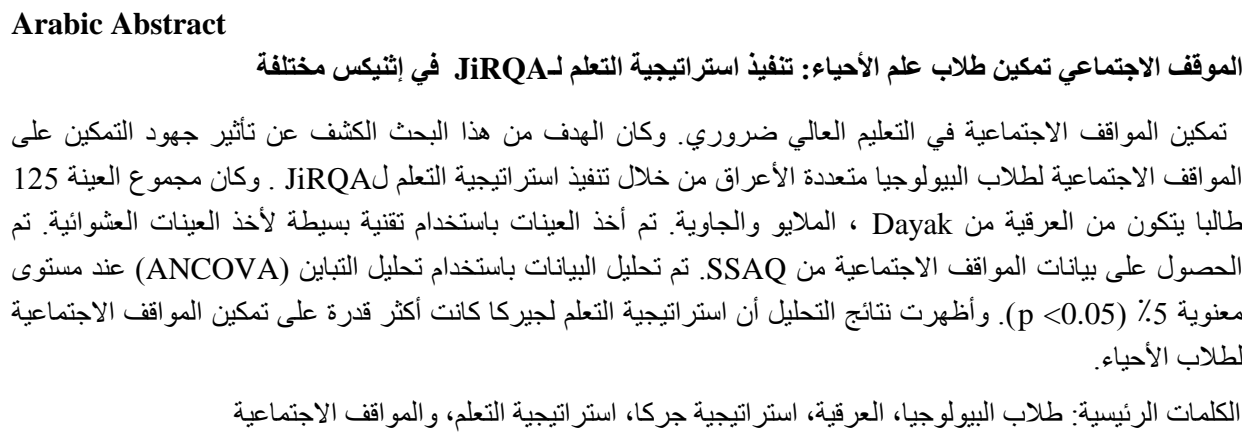




\title{
German Abstract \\ Die soziale Einstellung Empowerment der Biologie Studenten: Umsetzung JiRQA Lernstrategie in verschiedenen Ethniken
}

Die Ermächtigung der gesellschaftlichen Einstellungen in der Hochschulbildung ist unentbehrlich. Ziel dieser Forschung war es, die Wirkung der Empowerment-Bemühungen auf die soziale Haltung der multiethnischen Biologie-Studenten durch die Umsetzung der JiRQA Lernstrategie aufzudecken. Die Gesamtprobe betrug 125 Schüler, bestehend aus Ethnik von Dayak, Malaiisch und Javanisch. Die Proben wurden mit einfacher Stichprobenverfahren durchgeführt. Die Daten der sozialen Einstellungen wurden von SSAQ erhalten. Die Daten wurden unter Verwendung der Analyse der Kovarianz (ANCOVA) mit dem 5\% Signifikanzniveau $(p<0,05)$ analysiert. Die Ergebnisse der Analyse zeigten, dass die JiRQA Lernstrategie mehr Potenzial für die Stärkung der sozialen Einstellungen von Biologie-Studenten warkeln.

Schlüsselwörter: biologie studenten, ethnik, JiRQA strategie, lernstrategie, soziale einstellungen

\section{Malaysian Abstract \\ Memperkasa Sikap Sosial Biologi Pelajar: Pelaksanaan JiRQA Strategi Pembelajaran dalam Kalangan Suku Bangsa Berbeza}

Memperkasakan sikap sosial dalam pendidikan tinggi adalah amat diperlukan. Tujuan kajian ini adalah untuk mendedahkan kesan daripada usaha pemerkasaan pada sikap sosial pelajar biologi pelbagai etnik melalui pelaksanaan strategi pembelajaran JiRQA. Jumlah sampel adalah 125 orang pelajar yang terdiri daripada etnik Dayak, Melayu dan Jawa. Sampel telah diambil dengan menggunakan teknik persampelan rawak mudah. Data sikap sosial diperoleh daripada SSAQ. Data dianalisis dengan menggunakan analisis kovarians (ANCOVA) pada aras keertian 5\% (p $<0.05$ ). Keputusan analisis menunjukkan bahawa strategi pembelajaran JiRQA lebih berpotensi dalam memperkasakan sikap sosial pelajar biologi.

Kata Kunci: pelajar biologi, etnik, strategi JiRQA, strategi pembelajaran, sikap sosial

\author{
Russian Abstract \\ Укрепление Социальной Позиции Студентов-Биологов: Внедрение Стратегии \\ Обучения JiRQA (Головоломка, Чтение, Вопрос, Ответ) в Разных Этнических \\ Группах
}

Расширение возможностей социальных отношений в высшем образовании является необходимым. Цель этого исследования состояла в том, чтобы раскрыть влияние усилий по расширению прав и возможностей на социальные отношения этнической группы студентов-биологов, посредством реализации стратегии обучения JiRQA. Общая выборка состояла из 125 студентов, состоящих из этнических групп Даяк, Малай и Яванцев. Образцы были взяты с использованием простого метода случайного отбора. Данные социальных отношений были получены из SSAQ. Данные анализировали с использованием анализа ковариации (ANCOVA) при уровне значимости $5 \%(\mathrm{p}<0,05)$. Результаты анализа показали, что стратегия обучения JiRQA была более потенциальной в расширении возможностей социальных взглядов студентов-биологов.

Ключевые Слова: студентов-биологов, этники, стратегия JiRQA, стратегия обучения, социальные отношение 